\title{
The Influence of Theory of Planned Behavior, Technology Acceptance Model, and Information Systems Success Model on the Acceptance of Electronic Tax Filing System in an Emerging Economy
}

Gaurav Gupta. Pacific Lutheran University. USA. guptaga@plu.edu

Syed K. Zaidi. Midwestern State University. USA. syed.zaidi@mwsu.edu

Godwin Udo. The University of Texas at El Paso. USA. gudo@utep.edu

Kallol Bagchi. The University of Texas at El Paso. USA. kbagchi@utep.edu

\begin{abstract}
Adoption studies on electronic tax-filing system using data from emerging nations are rare. The present paper studies the influence of perceived ease of use, perceived usefulness, and user satisfaction on taxpayers' behavioral intentions to adopt electronic tax filing services in an emerging economy. For this study, constructs from Theory of Planned Behavior (Ajzen, 1985, 1991), Technology Acceptance Model (Davis, 1989), and Information Systems Success Model (DeLone \& McLean, 1992) are used. In order to test the impact of perceived ease of use, perceived usefulness, and user satisfaction on behavioral intentions to adopt online tax filing system, we develop several hypotheses. The data is collected from 201 respondents who filed taxes using government or private vendor websites. A structural equation modeling scheme using PLS is used to analyze the model. The measurement model not only shows structural validity but also demonstrates adequate predictive and explanatory quality. A strong support for a majority of hypotheses is found.
\end{abstract}

Keywords: Online Tax Filing; Technology Acceptance Model; Information Systems Success Model; Intentions; Taxpayers. 


\section{INTRODUCTION}

Although many governments in both developed and developing nations have made good progress in delivering digital services to their citizens, most of them are still overwhelmed by the complexity of the technology and their own bureaucracy. One purpose of providing government e-services is to promote the accessibility and ease of providing essential government services to its citizens (Carter \& Belanger, 2005). However, the citizens are less satisfied with e-services for a number of reasons such as skepticism, lack of digital skills, lack of trust in the systems, confusion resulting from poor instructions, etc. (Lee et al., 2011). It has become obvious that the future is trending more towards online delivery of government services such as education, housing, justice, taxation, social services, etc. The intense research interest in this area is a reflection of its importance and of how little is known about electronic government (e-government) service delivery and the users' success factors. To enhance effectiveness in government online service delivery, the barriers to increase online user satisfaction must be identified and addressed by respective governments. From website design and quality of online service to assurance of privacy, barriers must be sufficiently addressed in order to increase users' desire to continue using e-services provided by governments to their citizens (Chen et al., 2015).

Electronic filing (e-filing) is one of the many types of government services delivered online that is treated with increased importance and popularity ( $\mathrm{Fu}$ et al. ,2006). Although e-filing is getting adopted by citizens of many nations, Azmi and Kamarulzaman (2010, p. 599) note that "it is yet to establish an integrated system that is reliable, especially in developing countries." More studies need to be conducted in order to find an adequate conceptual model for e-filing, especially in the context of developing nations and the present study is an effort in that direction. The contribution of this work includes combining three theoretical models to generate a rich model to study the factors of e-filing in a developing country environment such as India.

Another contribution of this research is to examine if the western models of technology adoptions could be examined in developing countries. Thus, the current research focuses on the adoption of an online tax filing service by taxpayers in India. We select India for several reasons. First, there is a dearth of 
literature on the use of online tax filing systems in India. We find one study by Ojha et al. (2009) that examine the antecedents of intentions to adopt online tax filing in India. However, this study is limited in scope because of their model and the use of student sample to collect the data. Combining constructs from the Theory of Planned Behavior, the Technology Acceptance Model, and Information Systems Success Model, (Ajzen, 1985; Davis, 1989; Ajzen, 1991; DeLone \& McLean, 2003), we use a comprehensive approach to study behavioral intentions to adopt online tax filing.

Second, we find evidence that Indian government is investing extensively in eservices. One such e-service launched recently is Electronic Fund Management System (eFMS), which disburses wages to beneficiaries under the National Rural Guarantee Scheme (United Nations E-government Survey, 2014). However, an electronic system can provide its benefits only when users adopt it. Moreover, the adoption of an e-government cannot be assumed (Udo \& Bagchi, 2011). Ojha et al. (2009) conclude that the adoption of electronic tax filing in India has been slow. Our research seeks to bridge this gap by providing evidence of factors that are crucial for the successful implementation of e-government services in India.

We hope that our holistic approach will help government administrators in other emerging economies in making technology diffusion decisions. With this aim in mind, we address the following research questions in this study: why are some taxpayers more willing to adopt the e-filing systems than the others? And what are the factors affecting users' satisfaction with the system and their intention to use the system?

The remaining paper is organized as follows: the next section reviews current technology adoption literature followed by the theoretical framework for the efiling system adoption leading to hypotheses development. The following section describes the research method, including data collection and measurement of variables. The data analysis and hypothesis testing are then discussed. The next section provides a discussion of results. The last section concludes the paper, discusses the implications of findings, studies limitations of this research, and provides some future research options. 


\section{LITERATURE REVIEW AND HYPOTHESES DEVELOPMENT}

Adoption of e-filing has been studied in past. Electronic filing (or e-filing) offers several aspects of convenience such as time to file, place to conduct electronic filing, and ease of use, (Azmi \& Kamarulzaman, 2010). Fu et al. (2006) observe that perceived risk influences the intention of citizens who use e-filing. Azmi and Kamarulzaman (2010) use a modified Technology Acceptance Model (TAM) by adding a perceived risk construct to TAM construct, making it more appropriate to e-filing adoption scenario. Chen et al. (2015) combine trust theory and Information Systems Success Model (ISSM) to study e-filing adoption. The authors observe that information quality, system quality, and service quality are important to taxpayers in using the online system.

The present study is based on the following three well-known theories: Theory of Planned Behavior (TPB); Technology Acceptance Model (TAM), and Information Systems Success Model or ISSM (Ajzen, 1985; Davis, 1989; Ajzen, 1991; DeLone \& McLean, 1992). TPB has been extensively utilized in research to study factors (attitude, subjective norm, and perceived behavioral control) that influence intentions to engage in a particular behavior. We utilize TPB to examine factors that influence taxpayers' intentions to adopt online tax filing. Hung et al. (2006) state that TPB provides a robust theoretical framework for predicting the adoption of new technologies. Other studies (Harrison et al., 1997; Pavlou \& Fygenson, 2006) have extensively utilized TPB in their research.

TAM states that technology acceptance is dependent on users' perceived ease of use (PEoU) and perceived usefulness (PU). Perceived ease of use refers to the extent to which a user believes that using a new information system demands little or no effort; while perceived usefulness is the degree to which a user believes that using new information system would enhance task performance (Davis, 1989). Hong et al. (2002, p. 99) establish that "TAM develops a framework to establish the effects of external variables on the system usage." Davis (1989) posits that PU significantly influences intention to use a system. TAM is parsimonious in nature and many existing studies have synthesized TAM and other theories to a generalized model or have used a few other constructs along with TAM constructs to develop an extended version of TAM (Lee et al., 2003; Venkatesh et al., 2003; Wallace \& Sheetz, 2014). Wallace and Sheetz (2014) utilize TAM to explain the 
acceptance of software measures in organizations. Software measure refers to "any tool that provides a quantitative assessment of the degree to which a software product or process possess a given attribute such as size, complexity or quality" (Wallace \& Sheetz, 2004, p. 249). The authors find that perceived usefulness and perceived ease of use positively influence the use of software measures. Al-Hujran et al., (2015) examine the low level of adoption of online egovernment services. The authors use TAM (Davis, 1989) and factors such as trust, perceived public value, and national culture, to develop a model of adoption of e-government services. The authors find that users' attitude is significant in explaining adoption of e-government. Results suggest that attitude is jointly explained by perceived public value and perceived ease of use.

The ISSM is a multidimensional and an interdependent instrument used for assessing information systems success. One of the dimensions of ISSM, systems quality, measures the technical success while another dimension, information quality, measures the semantic success (DeLone \& McLean, 2003). The third major dimension of ISSM is service quality (DeLone \& McLean, 2003). In context of online tax filing in Philippines, Chen et al. (2015) find that trust in egovernment significantly affects the perceptions about information, system, and service quality.

In essence, the present study uses constructs that are derived from TPB, TAM, and ISSM (Ajzen, 1985, Davis, 1989; Ajzen, 1991; DeLone \& McLean, 2003) to explore the relationships among several predictor and outcome variables identified in this research for providing guidance about the tax filers' intentions to continue using the system electronically.

\subsection{Convenience of Service $(\mathrm{CoS})$ :}

Morganosky (1986, p. 37) states that a convenience-oriented customer aims to "accomplish a task in the shortest time with the least expenditure of human energy." Berry et al. (2002) provide a model of service convenience and state that service convenience is consumers' time and effort perceptions of (1) decision convenience, (2) access convenience, (3) transaction convenience, (4) benefit convenience, and (5) post benefit convenience. Using Berry et al. (2002) framework, Colwell, et al. (2008) find that service convenience is positively 
associated with customer satisfaction. Similarly, Kim et al. (2006) find that convenience of an online market place positively influences customer satisfaction. Moreover, prior studies such as Srinivasan et al. (2002) and Torkzadeh and Dhillon (2002) find that service convenience affects perceived service quality and customer satisfaction. However, Zhang and Prybutok (2005) do not find conclusive evidence that $\mathrm{CoS}$ affects perceived service quality and user satisfaction. Consistent with most prior research, we expect to find a positive relationship between $\mathrm{CoS}$ and web service quality, and $\mathrm{CoS}$ and taxpayers' satisfaction. The related hypotheses to be tested are:

H1: Convenience of service is positively associated with web service quality.

H2: Convenience of service is positively associated with taxpayer satisfaction.

\subsection{Web Service Content (WSC)}

WSC is primarily concerned with the presentation and layout of the information on the website. WSC is a depiction of the image that any organization wants public to see. It can be used to alter customers' perception of web service quality (Huang, 2000; Chen \& Macredie, 2005; Liao et al., 2006). WSC includes dimensions such as "information quality, appropriateness of the amount of information, types of media, presentation mode, size and types of the images, and the overall appeal of the website" (Udo et al., 2008, p. 316). According to Koernig (2003), WSC positively influences users' attitudes toward the quality of e-services they receive, which in turn, can affect behavioral intentions of users. In case of e-filing, we expect that effective WSC can lead to positive perceptions about web service quality. Therefore, the corresponding hypothesis is:

H3: Web service content is positively associated with web service quality.

\subsection{Web Service Quality (WSQ)}

System service quality can influence systems performance. Han and Baek (2004) state that service quality can help a firm build a competitive advantage. Summarizing the findings of prior research in this area, Parasuramam et al. (2005) argue that the acceptance of technologies by consumers are dependent on their beliefs about the technology, and differences in these beliefs may also lead to differences in evaluation of e-service quality. In an online purchase setting, "WSQ 
encompasses interactions between humans and technology" (Kim et al. 2006, p. 53). As such, it is important to examine the impact WSQ has on user satisfaction. WSQ affects e-customers' first impression which forms the basis for their decision to buy or not to buy and the decision to continue receiving such services in future (Barnes \& Vidgen, 2006). According to Lee and Lin (2005), website content and perceived risk of individual users affect WSQ, which in turn, affects overall customer satisfaction. Chen et al. (2015) believe that WSQ, which consists of information quality, system quality, and service quality, has a positive impact on perceived usefulness and user satisfaction. User satisfaction levels increase when government websites rank high on WSQ. This is likely to boost their behavioral intentions to use e-services including e-filing. Therefore, we hypothesize that:

H4: Web service quality is positively associated with taxpayers' satisfaction.

\subsection{Perceived Risk (PR):}

Perceived Risk in online transactions has been considered as one of the major impediments of successful online transactions (Udo et al., 2010). PR is defined as "the potential for loss in the pursuit of a desired outcome of using an e-service" (Featherman \& Pavlou, 2003, p. 454). In context of our research, perceived risk refers to the risks perceived by tax filers while filing taxes electronically. According to Lopez-Nicolas and Molina-Castrillo (2008), PR is also known by other terms such as personal risk, privacy risk, economic risk, psychological risk, and technological risk. Perception of risk by users always lead to low user satisfaction, low perceived quality of service, and less intention to continue using system in question. Gefen et al. (2003) find that PR negatively impacts shopping behavior and e-purchasing intentions. Zhang and Prybutok (2005) also conclude that PR has a negative and significant influence on both satisfaction and perception of digital service quality. In a study of adoption of online tax filing and payment system in Taiwan, Hung et al. (2006) find that PR negatively influenced tax filers' attitudes about government e-services. As such, citizens need to be assured that perceived risks are mitigated and that their interests are protected by their government. The three PR related hypotheses to be tested are: 
H5: Perceived risk in online tax filing is negatively associated with web service quality.

H6: Perceived risk in online tax filing is negatively associated with taxpayers' satisfaction.

H7: Perceived risk in online tax filing is negatively associated with taxpayers' behavioral intentions to adopt online tax filing.

\subsection{Perceived Usefulness (PU)}

One of the TAM's premises is that users will continue using the system after their initial experience if they perceive that system to be useful. PU of a system is partly measured by net benefits that users obtain from the system (Chen et al., 2015). According to Davis (1989), PU is the perceived likelihood that a system can help users perform their tasks more easily than if the system is not used. PU is one of the strongest constructs of TAM. Lee et al. (2003) observe that the relationship between PU and intentions emerged significant in 74 out 101 prior studies (p. 759). Researchers (Gefen et al., 2003; Udo et al., 2010) find that PU is significant in determining users' intention to use online systems. Other studies (Srite \& Karahanna, 2006; Castaneda et al., 2007; Ong et al., 2009; Chen et al., 2015) also conclude that PU is a significant factor in determining user satisfaction and intentions to use the system. However, Lin et al. (2011) do not find any significant relationship between perceived usefulness and intentions to use internet (e-government services in Gambia) to complete applications.

In case of electronic tax filing, benefits may include reduction in errors made, amount of time saved, faster refund time, etc. It is expected that a useful e-filing system will enhance user satisfaction and behavioral intention to use the system. Therefore, we present the following hypotheses:

H8: Perceived usefulness is positively associated with taxpayers' satisfaction.

H9: Perceived usefulness is positively associated with taxpayers' behavioral intentions to adopt online tax filing. 


\subsection{Computer and Web Skills (C\&WS)}

The ability of customers to utilize the available technology for making online transactions can influence the outcome of that service experience (Udo et al., 2010). The authors further state that traditional service encounters differ from online service experiences because in online encounters, customers use their ability to utilize technology in obtaining services and becoming partners in the delivery of the online service (Kuisma et al., 2007; Kim et al., 2009). This phenomenon is often described as self-efficacy (Porter \& Donthu, 2006). Ford et al. (2003) establish that a strong relationship exists between individual differences and behavior in internet search. Rowley (2006) argues that enhancing customers' knowledge about a service process is one of the flagship organizational strategies that help improve customer satisfaction. The author maintains that companies not only need to provide good website design and clear navigation instructions, but also need to implement learning processes to help customers become more skillful in making online transactions. The corresponding hypothesis for CS is as follows:

H10: Taxpayers' computer and web skills are positively associated with their perceived ease of use of online tax filing.

\subsection{Perceived Ease of Use (PEoU)}

PEoU is one of the four variables in TAM, a popular and reliable model in many studies. Kim et al. (2009) show that PEoU affects user satisfaction and intentions to use the system. As mentioned earlier, TAM theorizes that both PEoU and PU influence intentions to use technology. Later studies have shown that PEoU may not always directly influence intentions. Lee et al. (2003) observe that the relationship between PEoU and intentions emerged as significant in 58 out of 101 prior studies (p. 759). As mentioned earlier, TAM suggests that PEoU and PU influence intentions to use technology. However, some studies (Keil et al., 1995) show that PEoU may not always directly influence intentions. On the other hand, Cho and Sagynov (2015) investigate the effects of PEoU and perceived usefulness on internet shopping. The authors conclude that both factors affect behavioral intentions. Other studies (Shih, 2004; Kuisma et al., 2007; Kim et al., 2009; Yoon, 2009) find that PEoU influences user satisfaction and behavioral intentions. Fu et al. (2006) compare manual and electronic tax filers and find that the effects 
of PEoU and CS on behavioral intention are different for both groups of tax filers. The electronic filers value PEoU more than the manual filers. Collecting data from users of e-government in Gambia, a country in West Africa, Lin et al. (2011) find perceived ease of use to be a significant predictor of perceived usefulness of using internet to complete applications. The authors, however, do not test the direct relationship between perceived ease of use and intentions. In context of online tax filing, we test the following hypotheses:

H11: Perceived ease of use of online tax filing is positively associated with taxpayers' satisfaction.

H12: Perceived ease of use of online tax filing is positively associated with taxpayers' behavioral intentions to adopt online tax filing.

\subsection{User Satisfaction (US)}

User satisfaction is an effective construct used in numerous studies to evaluate the success of any given system (DeLone \& McLean, 2003). High US (as perceived by customers) leads to favorable behavioral intentions while low US lead to unfavorable behavioral intentions (Udo \& Bagchi, 2011). Collecting data from end users of Business Intelligence (BI) systems in Taiwanese electronics industry, Hou (2012) examines relationships among the following variables: end-user computing satisfaction (EUCS), system usage, and individual performance. The author finds significant positive relationships between EUCS and system usage, and between system usage and individual performance.

In context of e-government services, citizens can be satisfied when their needs and wants are considered and prioritized in designing the systems that deliver such services. In case of online tax filing, filing process must be easy to use, forgiving if errors are made, convenient, of high service quality, and free of unnecessary risks. Therefore, our final hypothesis is as follows:

H13: Taxpayers' satisfaction is positively associated with their behavioral intentions to adopt online tax filing.

\subsection{Behavioral Intention (BI)}

Behavioral Intentions are defined as "the strength of conscious plans to perform the target behavior" (Harrison et al., 1997, p. 176). Zeithaml et al. (1996) assert 
that behavioral intentions can be measured by actions such as repeat purchase, loyalty, and decision to consistency. Zhang and Prybutok (2005) find that customer experiences are related to behavioral intentions. Udo et al. (2010, p. 485) state that "the more positive the customer's experience, the more likely he or she is willing to reuse the service." Moreover, prior research (Rai et al., 2002; Venkatesh et al., 2003; Udo et al., 2010) successfully utilize BI as a measure of system success.

Several researchers (Al-Hujran et al., 2015; Chen et al., 2015; Fakhoury \& Aubert, 2015; Rana \& Dwivedi, 2015) examine the factors that are useful in the adoption of e-government services. Utilizing the extended social cognitive theory, Rana and Dwivedi (2015) examine the influence of several factors such as affect, anxiety, and social influence, on users' behavioral intentions to adopt online public grievance redressal system (OPGRS), an e-government system in India. The authors find that affect and social influence positively, whereas anxiety negatively influences the participants' intentions to adopt online tax filing.

\section{RESEARCH METHOD}

This study uses a survey-based methodology to collect data from taxpayers. We use WarpPLS 5.0 to perform Structural Equation Modeling (SEM). Details on variables, model, and sample are provided in the following sections.

\subsection{Variables}

The dependent variable is taxpayers' behavioral intentions (BI) to file taxes online. Independent variables are convenience of service $(\mathrm{CoS})$, perceived ease of use (PEoU), computer and web skills (C\&WS), web services control (WSC), user satisfaction (US), perceived usefulness (PU), web service quality (WSQ), and perceived risk (PR). We use several theories from extant literature (Ajzen, 1985; Davis, 1989; Ajzen, 1991; DeLone \& McLean, 1992; Hofstede, 2001; DeLone \& McLean, 2003; Srite \& Karahanna, 2006; Udo et al., 2010; Udo \& Bagchi, 2011) to establish our model and to adapt the instrument used to measure our research variables. 


\subsection{Model}

Based on extant accounting and information systems literature, we develop and test a model as described above that explains taxpayers' behavioral intentions to e-file taxes (Figure 1). We use Structural Equation Modeling to test our hypotheses. Our model shows the impact of perceived ease of use, user satisfaction, perceived usefulness, and perceived risk on tax payers' behavioral intentions to file taxes online. In addition, the figure also shows the impact of perceived ease of use, perceived usefulness, perceived risk, web service quality, and convenience of service on user satisfaction. The model also investigates the effect of computer and web skills on perceived ease of use. Our model also examines the impact of convenience of service, web service content, and perceived risk on web service quality.

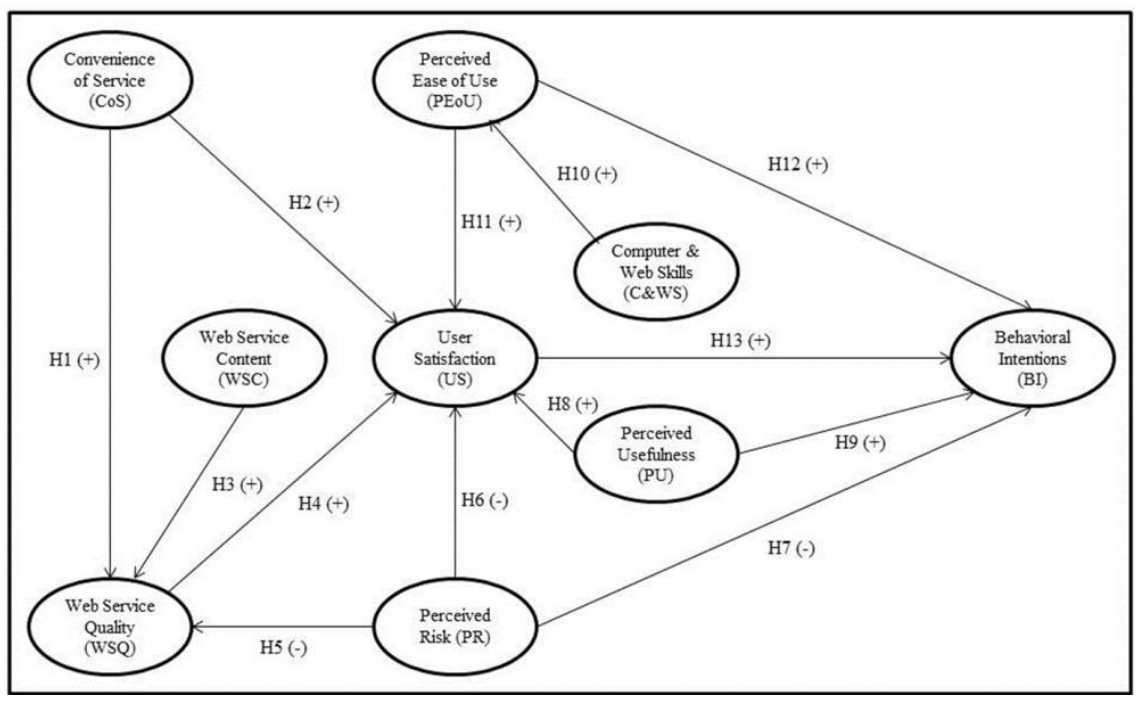

Figure 1. Online Tax Filing Model (with Hypotheses)

\subsection{Sample}

We utilize snowball sampling method to collect the data. Participants are asked not to complete the survey if they have never utilized either Indian government tax website (http://www.taxindia.gov.in) and/or private vendor websites such as http://www.etaxmentor.com, http://www.taxspanner.com, or any other tax filing website to e-file theirs or someone else's (other individual or business) income taxes. In our research, taxpayers also include tax filers who used e-filing to file 
someone else's taxes. As such, the data for this study is collected from both taxpayers and tax filers. Our final sample consists of 201 participants. The average experience of participants in accounting or accounting related field is 7.65 years whereas the average experience of participants in non-accounting related field is 4.85 years. A majority (145 respondents) of participants mention that they are currently working in accounting or accounting related field. On a 5-point Likert scale, participants are asked to rate between 1 (low, strongly disagree, bad idea, or very foolish) and 5 (high, strongly agree, good idea, or wise). The final part of our survey consists of demographic information about the participants (Table 1).

\begin{tabular}{|c|c|c|}
\hline \multicolumn{3}{|l|}{ Total Responses (N) } \\
\hline Gender & & \\
\hline Female & 43 participants & $21.39 \%$ \\
\hline Male & 156 participants & $77.61 \%$ \\
\hline No response & 2 participants & $1.00 \%$ \\
\hline \multicolumn{3}{|l|}{ Age } \\
\hline Less than 18 years & 0 participants & $0 \%$ \\
\hline $18-24$ years & 51 participants & $25.37 \%$ \\
\hline $25-35$ years & 95 participants & $47.26 \%$ \\
\hline $36-50$ years & 51 participants & $25.37 \%$ \\
\hline Over 50 years & 4 participants & $1.99 \%$ \\
\hline Internet Experience & 6.98 years (average) & \\
\hline \multicolumn{3}{|l|}{ Work Experience (Accounting) } \\
\hline Average number of years & 161 participants -7.65 years & $80.10 \%$ \\
\hline No response/other & 40 participants & $19.90 \%$ \\
\hline \multicolumn{3}{|l|}{ Work Experience (Non-Accounting) } \\
\hline Average number of years & 163 participants -4.85 years & $81.09 \%$ \\
\hline No response & 38 participants & $18.91 \%$ \\
\hline \multicolumn{3}{|l|}{ Current Employment } \\
\hline Accounting related field & 145 participants & $72.14 \%$ \\
\hline Non-accounting related field & 55 participants & $27.36 \%$ \\
\hline No response & 1 participant & $0.50 \%$ \\
\hline \multicolumn{3}{|l|}{ Online Tax Filing Experience } \\
\hline Personal & 108 participants & $53.73 \%$ \\
\hline Corporate & 13 participants & $6.47 \%$ \\
\hline Other & 11 participants & $5.47 \%$ \\
\hline Personal and corporate & 44 participants & $21.89 \%$ \\
\hline Personal and other & 2 participants & $1.00 \%$ \\
\hline Corporate and other & 2 participants & $1.00 \%$ \\
\hline Personal, corporate, and other & 19 participants & $9.45 \%$ \\
\hline No response & 2 participants & $1.00 \%$ \\
\hline
\end{tabular}

Table 1.Demographics 


\section{ANALYSIS AND RESULTS}

Table 2 exhibits Model fit Indices. Average Path Coefficient (APC) is 0.204, which is significant at $0.1 \%$ level. In addition, Average R-Squared (ARS), and Average Adjusted R-Squared (AARS) are 0.312 and 0.302, respectively. Both ARS and AARS are significant at $0.1 \%$ level. These indices and their significance level suggest a good model fit. Average Block VIF (AVIF) is 1.392 and the Average Full Collinearity VIF (AFVIF) is 1.729. They both fall under the ideal range. Both AVIF and AFVIF show model's overall predictive and explanatory quality.

The Tenehaus Goodness of Fit (GoF) is 0.451 . The ideally acceptable value for GoF is equal to or greater than 0.36. The obtained GoF value shows that our model has a higher explanatory power. In addition, our model shows Simpson's Paradox Ratio (SPR) of 0.923, which is greater than the acceptable value of 0.7 . This suggests that the paths in our model are free from Simpson's paradox or causality problem ${ }^{1}$. Moreover, the value of R-Squared Contribution Ratio (RSCR) is also acceptable (0.997) and is very close to the ideal value of 1 . Finally, Statistical Suppression Ratio (SSR) is ideal, whereas Nonlinear Bivariate Causality Direction Ratio (NLBCDR) is acceptable. Overall, our model depicts a higher predictive power.

\begin{tabular}{l|l}
\hline Model Fit & Indices \\
\hline Average path coefficient (APC) & $0.204 * * *$ \\
Average R-squared (ARS) & $0.312^{* * *}$ \\
Average adjusted R-squared (AARS) & $0.302^{* * *}$ \\
Average block VIF (AVIF) & 1.392 \\
Average full collinearity VIF (AFVIF) & 1.729 \\
TenenhausGoF (GoF) & 0.451 \\
Simpson's paradox ratio (SPR) & 0.923 \\
R-squared contribution ratio (RSCR) & 0.997 \\
Statistical suppression ratio (SSR) & 1.000 \\
Nonlinear bivariate causality direction ratio (NLBCDR) & 0.885 \\
\hline$* *$ P $<0.001$ &
\end{tabular}

Table 2. Model Fit and Quality Indices

\footnotetext{
${ }^{1}$ According to Kock (2013), Simpson's paradox 'occurs when a path coefficient and a correlation associated with a pair of linked variables have different signs' (p. 49). This may indicate a causality problem, which means that 'a hypothesized path is either implausible or reversed' (Kock, 2013 ; p. 49).
} 


\begin{tabular}{|c|c|c|}
\hline Construct and Indicators & Loadings & $\begin{array}{c}\text { Cronbach's } \\
\text { Alpha }\end{array}$ \\
\hline $\begin{array}{l}\text { Computer and Web Skills (CandWS) } \\
\text { - } \quad \text { Rate your skill in Microsoft Word. } \\
\text { - } \quad \text { Rate your skill in Microsoft Excel. } \\
\text { - } \quad \text { Rate your skill in Microsoft PowerPoint. } \\
\text { - } \quad \text { Rate your skill in Microsoft Access. } \\
\text { - } \quad \text { Rate your skill in using the Internet. } \\
\end{array}$ & $\begin{array}{l}0.827 \\
0.733 \\
0.764 \\
0.549 \\
0.688\end{array}$ & 0.759 \\
\hline $\begin{array}{l}\text { Perceived Ease of Use (PEoU) } \\
\text { - It was easy to use the e-service (i.e. file taxes online). } \\
\text { - } \quad \text { The language to me was clear and easy to understand. }\end{array}$ & $\begin{array}{l}0.860 \\
0.860 \\
\end{array}$ & 0.648 \\
\hline $\begin{array}{l}\text { Perceived Usefulness (PU) } \\
\text { - } \quad \text { The tax filing website offered adequate user guidelines to help me. } \\
\text { - } \quad \text { My needs/queries were adequately addressed by the tax filing website. }\end{array}$ & $\begin{array}{l}0.855 \\
0.855\end{array}$ & 0.631 \\
\hline $\begin{array}{l}\text { User Satisfaction (US) } \\
\text { - } \quad \text { I was well satisfied with my online tax-filing experience. } \\
\text { - } \quad \text { Online tax filing was a pleasant experience. } \\
\text { - } \quad \text { Overall, I was satisfied with online tax filing experience. }\end{array}$ & $\begin{array}{l}0.796 \\
0.883 \\
0.910\end{array}$ & 0.829 \\
\hline $\begin{array}{l}\text { Web Service Quality (WSQ) } \\
\text { - } \quad \text { The web vendor gave prompt service to customers. } \\
\text { - } \quad \text { It was easy to find what you were looking for. } \\
\text { - } \quad \text { The tax filing website seemed to be up to date. }\end{array}$ & $\begin{array}{l}0.794 \\
0.775 \\
0.716\end{array}$ & 0.639 \\
\hline $\begin{array}{l}\text { Web Service Content (WSC) } \\
\text { - It was easy to navigate on the tax filing website. } \\
\text { - The information about the services for your tax filing needs was } \\
\text { sufficient to make a decision to file taxes online. } \\
\text { - The information about services on the tax filing website for you was } \\
\text { sufficient. } \\
\text { - The tax filing website had an ideal number of images/graphics. } \\
\text { - The graphics on the tax filing website were appealing. } \\
\text { - The contents of the tax filing website were useful for tax filing online. }\end{array}$ & $\begin{array}{l}0.547 \\
0.568 \\
0.687 \\
0.715 \\
0.798 \\
0.671\end{array}$ & 0.749 \\
\hline $\begin{array}{l}\text { Convenience of Service }(\mathbf{C o S}) \\
\text { - } \quad \text { Using the Internet made it easier for me to file taxes online. } \\
\text { - } \quad \text { Online tax filing was convenient. } \\
\text { - } \quad \text { Online tax filing saved time compared to filing taxes using traditional } \\
\text { paper-based tax filing. }\end{array}$ & $\begin{array}{l}0.818 \\
0.871 \\
0.855\end{array}$ & 0.805 \\
\hline $\begin{array}{l}\text { Perceived Risk (PR) } \\
\text { - I was worried about personal information being stolen. } \\
\text { - } \quad \text { I was worried about the service quality on the Internet. } \\
\text { - I was worried about safe tax filing transaction online. } \\
\text { - I was worried about how my personal information might be used when I } \\
\text { file taxes online. }\end{array}$ & $\begin{array}{l}0.822 \\
0.748 \\
0.868 \\
0.870\end{array}$ & 0.846 \\
\hline $\begin{array}{l}\text { Behavioral Intentions (BI) } \\
\text { - Given both the options to file taxes online and manually (paper-based), I } \\
\text { intend to use online tax filing frequently. } \\
\text { - Given both the options to file taxes online and manually (paper-based), I } \\
\text { intend to recommend online tax filing to other people. } \\
\text { - Given both the options to file taxes online and manually (paper-based), I } \\
\text { intend to use online tax filing service whenever I have a need. }\end{array}$ & $\begin{array}{l}0.855 \\
0.817 \\
0.847\end{array}$ & 0.791 \\
\hline
\end{tabular}

Table 3. Factor loadings 
The Cronbach's alphas for all of our constructs are greater than 0.60 . According to Nunnally (1967), the reliability of 0.50 to 0.60 is sufficient.

Latent variables exhibit significant indicator and cross loadings which suggests that they pass Confirmatory Factor Analysis (CFA) test. The highest Block Variance Inflation Factor (VIF) in our model is 1.891, which is below the threshold of 3.3 (Kock \& Lynn, 2012). The VIF values below 3.3 suggest that there is no vertical multicollinearity in a block of latent variables (Kock \& Lynn, 2012). Moreover, we drop one question (I was kept well informed of the tax law changes at the tax filing website), which fails to load at the acceptable level, from further analysis. The question was a part of web service content construct. Table 3 (in previous page) exhibits factor loadings and Cronbach's alphas of our constructs.

Furthermore, we also examine factor validity using convergent and discriminant validity. Correlations among latent variables with square roots of average variances extracted (AVE) are shown in Table 4. When the AVE (diagonal values as show in Table 4) is equal to or greater than 0.50 , a construct demonstrates the convergent validity (Udo et al., 2010). All values are greater than 0.50 , which suggests that our constructs show convergent validity. In addition, in order to assess convergent validity, we examine both combined loadings with cross-loadings and structure loadings with cross-loadings. All our loadings turn out to be greater than $0.5(\mathrm{p}<0.001)$ suggesting that the instrument displays good convergent validity (Hair et al., 1987; Hair et al., 2009).

We also examine discriminant validity of latent variables. According to Fornell and Lacker (1981), a latent variable displays discriminant validity when all of the correlations of that latent variable are less than the square root of the AVE. Correlations among latent variables are shown in Table 4. Results show that the diagonal value (the square root of the AVE) of any latent variable is greater than any of the correlations of that variable. Therefore, our construct shows convergent and discriminant validity. 


\begin{tabular}{l|lllllllll}
\hline & CoS & WSQ & WSC & PEoU & US & PR & C\&WS & PU & BI \\
\hline CoS & 0.848 & & & & & & & & \\
WSQ & $0.383^{* * *}$ & 0.762 & & & & & & & \\
WSC & $0.365^{* * *}$ & $0.551^{* * *}$ & 0.670 & & & & & & \\
PEoU & $0.469^{* * *}$ & $0.529^{* * *}$ & $0.611^{* * *}$ & 0.860 & & & & & \\
US & $0.631^{* * *}$ & $0.454^{* * *}$ & $0.528^{* * *}$ & $0.541^{* * *}$ & 0.864 & & & & \\
PR & $-0.195^{* *}-0.045$ & -0.111 & $-0.160^{*}$ & $-0.284^{* * *}$ & 0.829 & & & \\
C\&WS & 0.055 & 0.202 & $0.151^{*}$ & $0.130^{*}$ & $0.123^{*}$ & -0.002 & 0.718 & & \\
PU & $0.345^{* * *}$ & 0.426 & $0.492^{* * *}$ & $0.391^{* * *}$ & $0.581^{* * *}$ & $-0.226^{* *}$ & $0.213^{* *}$ & 0.855 & \\
BI & $0.380^{* * *}$ & $0.151^{* *}$ & $0.316^{* * *}$ & $0.256^{* * *}$ & $0.398^{* * *}$ & $-0.358^{* * *}$ & 0.010 & $0.388^{* * *}$ & 0.840 \\
\hline
\end{tabular}

${ }^{* * * *}$ Significant at $p<0.001 ;{ }^{* *}$ Significant at $p<0.01 ;{ }^{*}$ Significant at $p<0.10$ Diagonal represents square root of AVE values.

Table 4.Correlations among Latent Variables

WarpPLS 5.0 is used to perform Partial Least Square Structural Equation Modeling. Figure 2 shows confirmatory analysis model with results.

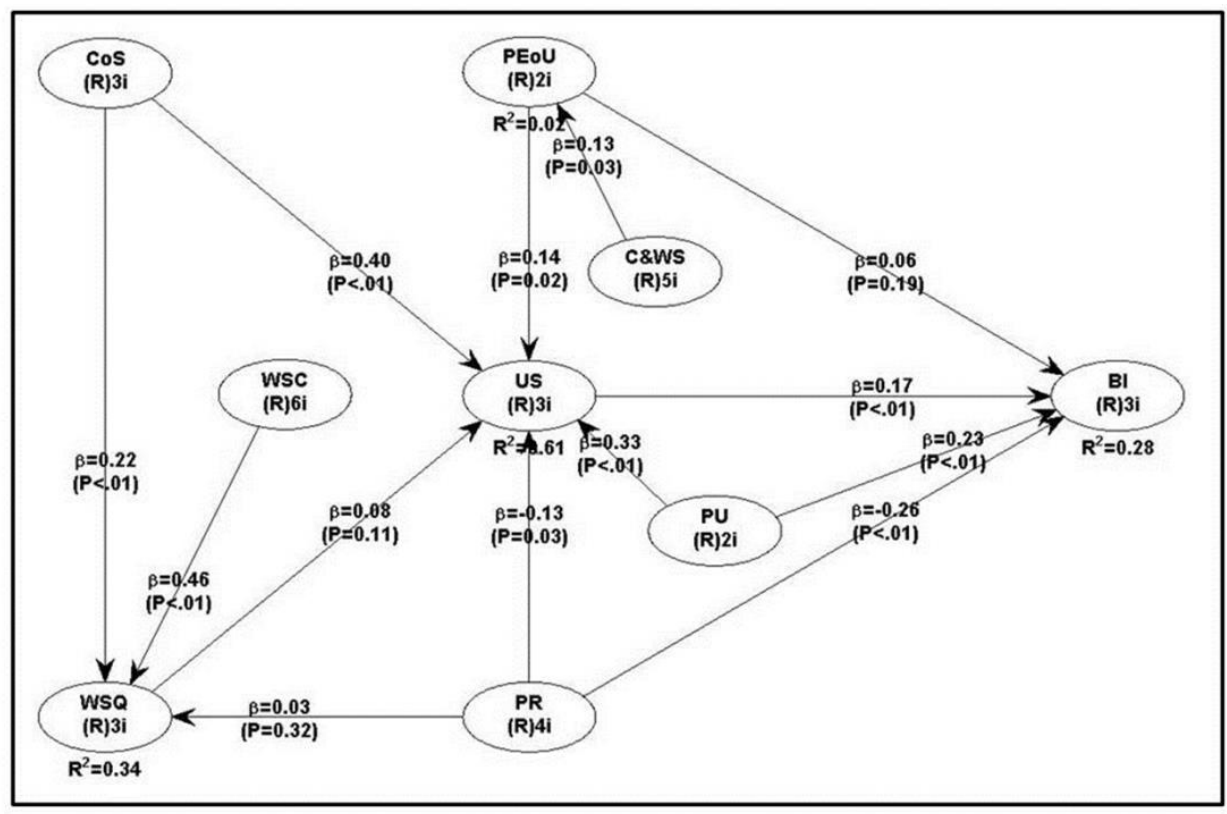

Figure 2. Online Tax Filing Model (with results) 
Our results show that convenience of service is positively and significantly $(\mathrm{p}<0.01)$ associated with both web service quality $(\mathrm{H} 1)$ and user satisfaction $(\mathrm{H} 2)$. Therefore, $\mathrm{H} 1$ and $\mathrm{H} 2$ are supported. Consistent with hypothesis 3, we find a positive and significant $(\mathrm{p}<0.01)$ relationship between web service content and web service quality. Thus, we find support for H3. However, we do not find any support for hypothesis 4 (web service quality is positively associated with taxpayers' satisfaction) and hypothesis 5 (perceived risk in online tax filing is negatively associated with web service quality).

Furthermore, our results show a negative and significant $(\mathrm{p}<0.05)$ relationship between perceived risk and taxpayers' satisfaction (H6) and a negative and significant $(\mathrm{p}<0.01)$ relationship between perceived risk and taxpayers' behavioral intentions to adopt online tax filing (H7). Consequently, H6 and H7 are supported. Moreover, we find that perceived usefulness is positively and significantly $(\mathrm{p}<0.01)$ associated with both taxpayers' satisfaction (H8) and taxpayers' behavioral intentions to adopt online tax filing (H9). Therefore, we find support for both $\mathrm{H} 8$ and $\mathrm{H} 9$.

Consistent with our hypotheses 10 and 11, our results show that perceived ease of use is positively and significantly $(\mathrm{P}<0.05)$ associated with taxpayers' computer and web skills (H10) and taxpayers' satisfaction (H11). Subsequently, $\mathrm{H} 10$ and $\mathrm{H} 11$ are supported. However, the association between perceived ease of use and taxpayers' behavioral intentions to adopt online tax filing (H12) is not found to be significant. Accordingly, H12 is not supported. We find strong support for $\mathrm{H} 13 \quad(\mathrm{p}<0.01)$, which suggests a positive relationship between taxpayers' satisfaction and taxpayers' behavioral intentions to adopt online tax filing. Table 5 reports results of our tested hypotheses.

\section{DISCUSSION}

We investigate the effect of perceived ease of use, perceived usefulness, and user satisfaction on taxpayers' behavioral intentions to adopt online tax filing. We integrate Technology Acceptance Model (Davis, 1989) and Information Systems Success Model (DeLone \& McLean, 1992) to evaluate taxpayers' behavioral intention to adopt electronic filing systems. Extensions of TAM-like models to study Internet-based systems have been suggested in literature (Lee et al., 2003). 
This work may also be considered as an effort to combine TAM and ISSM models using e-filing system on an emerging nation.

\begin{tabular}{|c|c|}
\hline Hypotheses & Supported \\
\hline H1: Convenience of service is positively associated with web service quality. & Yes \\
\hline $\mathrm{H} 2$ : Convenience of service is positively associated with taxpayer satisfaction. & Yes \\
\hline H3: Web service content is positively associated with web service quality. & Yes \\
\hline H4: Web service quality is positively associated with taxpayers' satisfaction. & No \\
\hline H5: Perceived risk in online tax filing is negatively associated with web service quality. & No \\
\hline H6: Perceived risk in online tax filing is negatively associated with taxpayers' satisfaction. & Yes \\
\hline $\begin{array}{l}\text { H7: Perceived risk in online tax filing is negatively associated with taxpayers' behavioral } \\
\text { intentions to adopt online tax filing. }\end{array}$ & Yes \\
\hline H8: Perceived usefulness is positively associated with taxpayers' satisfaction. & Yes \\
\hline $\begin{array}{l}\text { H9: Perceived usefulness is positively associated with taxpayers' behavioral intentions to } \\
\text { adopt online tax filing. }\end{array}$ & Yes \\
\hline $\begin{array}{l}\text { H10: Taxpayers' computer and web skills are positively associated with their perceived ease } \\
\text { of use of online tax filing. }\end{array}$ & Yes \\
\hline $\begin{array}{l}\text { H11: Perceived ease of use of online tax filing is positively associated with taxpayers' } \\
\text { satisfaction. }\end{array}$ & Yes \\
\hline $\begin{array}{l}\text { H12: Perceived ease of use of online tax filing is positively associated with taxpayers' } \\
\text { behavioral intentions to adopt online tax filing. }\end{array}$ & No \\
\hline $\begin{array}{l}\text { H13: Taxpayers' satisfaction is positively associated with their behavioral intentions to } \\
\text { adopt online tax filing. }\end{array}$ & Yes \\
\hline
\end{tabular}

Table 5. Results

We hypothesize (H1) that convenience of service is positively associated with web service quality. We expect to find a positive and significant relationship between convenience of service and web service quality of online tax filing systems. Our results show a positive and significant relationship between convenience of service and web service quality. Therefore, hypothesis 1 is supported. Udo et al. (2010) suggest a positive relationship between convenience of service and user satisfaction. Therefore, we hypothesize (H2) that convenience of service is positively associated with taxpayers' satisfaction. Our results show strong support for this hypothesis which suggests that the more conveniently a service is available, the more satisfied taxpayers will be.

Consistent with hypothesis 3 , web service content is positively associated with web service quality, we find strong support. However, we are unable to find any support for hypothesis 4 . The relationship between web service quality and taxpayers' satisfaction is found to be positive but not significant, which suggests web service quality does not have an effect on taxpayers' satisfaction. 
Furthermore, we hypothesize that perceived risk in online tax filing is negatively associated with web service quality (H5), taxpayers' satisfaction (H6), and taxpayers' behavioral intentions to adopt online tax filing (H7). Contrary to our expectations, we find a positive relationship between perceived risk and web service quality; however, this relationship is not significant. Therefore, hypothesis 5 is not supported. We do find support for hypotheses 6 and 7. The relationships between perceived risk and taxpayers' satisfaction (H6) and perceived risk and behavioral intentions (H7) are both negative and significant. This suggests that higher perceived risk associated with online tax filing system reduces both taxpayers' satisfaction and their behavioral intentions to adopt online tax filing system.

Moreover, we hypothesize that perceived usefulness is positively associated with both taxpayers' satisfaction (H8) and taxpayers' behavioral intentions to adopt online tax filing (H9). We find strong support for these hypotheses suggesting that higher perceived usefulness of online tax filing system not only enhances taxpayers' satisfaction (H8) but also augments their behavioral intentions to adopt online tax filing system (H9). This suggests that taxpayers will be more willing to use online tax payment system for filing current year and future year taxes if they perceive that the usefulness of the online tax filing system is high.

We further hypothesize that perceived ease of use of online tax filing system is positively associated with taxpayers' computer and web skills (H10), taxpayers' satisfaction (H11), and taxpayers' behavioral intentions to adopt online tax filing system (H12). We find support for hypotheses 10 and 11. Udo and Bagchi (2011) suggest that proficiency in computer and web skills positively affects the perceived ease of use of technology. In support of hypothesis 10, we find that taxpayers with higher computer and web skills will perceive that using online tax filing system is easy. This suggests that computer skills play crucial role in reducing the challenges associated with online activity. Therefore, taxpayers who are more proficient in computer and have greater web skills will have higher perception about the ease of use of online tax filing system. In addition, we find that taxpayers will be more satisfied if they perceive that online tax filing system is easy to use (H11). Contrary to our expectations, we do not find any support for 
hypothesis 12 . The relationship between perceived ease of use of online tax filing system and taxpayers' behavioral intentions to adopt online tax filing system is positive but not significant. We argue that due to the increased use of technology and internet in recent times, a wide range of people are already more proficient in using internet. Therefore, perceived ease of use may or may not lead to higher intentions of adopting online tax filing system. Taxpayers' adoption of online tax filing system may be affected by some other variables than perceived ease of use. This could be a reason we do not find support for our hypothesis 12 .

Our last hypothesis (H13) is related to taxpayers' satisfaction and behavioral intentions. Taxpayers' satisfaction indicates the degree to which individual taxpayers are satisfied using online tax filing system. We hypothesize that taxpayers' satisfaction is positively associated with taxpayers' behavioral intentions to adopt online tax filing. We find strong support for this hypothesis. Our results suggest that taxpayers will be more willing to adopt online tax filing system when their perceived level of satisfaction with the online tax filing system is higher. Therefore, hypothesis 13 is supported.

\section{CONCLUSION AND FUTURE RESEARCH}

This paper examines the impact of perceived ease of use, perceived usefulness, and user satisfaction on taxpayers' behavioral intentions to adopt electronic tax filing services in an emerging economy. We examine taxpayers' behavioral intentions to adopt electronic filing by incorporating Theory of Planned Behavior (Ajzen, 1985, 1991), Technology Acceptance Model (Davis, 1989), and Information Systems Success Model (DeLone \& McLean, 2003). We include data from taxpayers who have utilized government and private vendor tax filing portals to e-file taxes. In order to test the impact perceived ease of use, perceived usefulness, and user satisfaction have on behavioral intentions to adopt online tax filing system, we develop several hypotheses. We find strong support for a majority of our hypotheses (Table 5).

To the best of our knowledge, this is the first study to analyze the adoption of online tax filing in India from the perspectives of web service quality, web service content, convenience of service, and perceived risk. Our research model is holistic in nature as it is based on the three widely utilized technology adoption 
theories/models: Theory of Planned Behavior, Technology Acceptance Model, and Information Systems Success Model. Ojha et al. (2009) conduct a study to examine the antecedents of online tax filing in India. However, their study is exploratory in nature and focuses on identifying likely factors of adoption of online tax filing in India. Our holistic approach enables us to analyze important relationships among various variables in one single study. We find that perceived risk in online tax filing is an important factor that affects both taxpayers' satisfaction with the use of online tax filing system and their intentions to adopt online tax filing.

Further, our study is timely because of the growing role of India in the world economy as discussed in The Economist (2015):

Emerging markets used to be a beacon of hope in the world economy, they are more often a source of gloom. China's economy is slowing. Brazil is mired in stagflation. Russia is in recession, battered by Western sanctions and the slump in the oil price; South Africa is plagued by inefficiency and corruption. Amid the disappointment one big emerging market stands out: India.

This research has policy implications for the government of India as well as private e-tax portals as they use the results from this study in their technology diffusion decisions. Our research is in line with the recently initiated program, Digital India, by the Prime Minister, Narendra Modi. The vision of this program is to make India more digitized and knowledgeable society (Digital India, 2015). The three key vision areas of the program are:

1. Digital Infrastructure as a Core Utility to Every Citizen

2. Governance and Service on Demand

3. Digital Empowerment of Citizen

The recent initiative makes our research timely. We believe that our findings will help Indian government in its mission to successfully diffuse technology in a country of about 1.25 billion people. Specifically, we believe that our findings will help Indian government in designing and implementing systems for providing future e-services such as renewing driver's and business licenses. For successful adoption of e-filing and other e-services, our results suggest that Indian government may need to invest in factors such as education and training of its 
taxpayers, reducing perceived risk in e-services, using appropriate marketing strategies to promote the ease and usefulness of using e-services. Moreover, private e-tax filing portals could utilize our findings in improving the taxpayers' tax filing experiences, thereby increasing their customer base.

This is a survey based study and, therefore, we rely on self-reported measures. Consequently, we need to be very careful when we interpret results obtained from our study as self-reported measures are perceptual measures. Moreover, factors not included in our model, such as trust emotional intelligence, basic values of tax payers, etc. may have an impact on the adoption of an online tax filing system. Gupta (2015) recommends utilizing theory of basic human values (Schwartz, et $a l ., 2012)$ to measure taxpayers' values and analyze the moderating effects of these values on the relationships hypothesized in our research. Schwartz (1994, p. 21) defines these values as "desirable transsituational goals, varying in importance, that serve as guiding principles in the life of a person or social entity." Future research can be conducted by utilizing Schwarz's et al. (2012) values of power (dominance and resources), face, achievement, hedonism, humility, stimulation, self-direction (thought and action), universalism (concern, nature, and tolerance), benevolence (dependability and caring), tradition, conformity (rules and interpersonal), and security (personal and societal) to examine their moderating effects on our model ${ }^{2}$. This research will be of particular interest to diverse countries such as India which consists of multiple religions, languages, and cultures.

Featherman and Pavlou (2003) categorize perceived risk into the following six categories: performance risk, financial risk, time risk, psychological risk, social risk, privacy risk, and overall risk. Future research can be conducted to examine the influence of different dimensions of perceived risk on the relationships identified and established in our research. Furthermore, future research can be conducted to investigate the influence of interaction of basic human values (Schwartz et al., 2012) and facets of perceived risk (Featherman \& Pavlou, 2003) on the relationships identified in our research. Lastly, future research can also be conducted by utilizing the service convenience scale (Colwell et al., 2008) to

\footnotetext{
${ }^{2}$ For a detailed discussion on these values, review Schwartz et al. (2012).
} 
examine factors (decision, access, transaction, benefit, and post-benefit) that are significant predictors of satisfaction and web service quality, which are essential for the adoption of online services.

\section{REFERENCES}

AJZEN, I. (1985): "From Intentions to Actions: A Theory of Planned Behavior", in Action Control, eds. J. Kuhl and J. Beckmann, Berlin: Springer-Heidelberg, 1139. http://dx.doi.org/10.1007/978-3-642-69746-3_2

AJZEN, I. (1991): “The Theory of Planned Behavior", Organizational Behavior and Human Decision Processes, vol. 50: 179-211. http://dx.doi.org/10.1016/07495978(91)90020-T

AL-HUJRAN, O.; AL-DEBEI, M.M.; CHATFIELD, A.; MIGDADI, M. (2015): "The Imperative of Influencing Citizen Attitude Toward e-Government Adoption and Use", Computers in Human Behavior, vol. 53: 189-203. http://dx.doi.org/10.1016/j.chb.2015.06.025

AZMI, A.; KAMARULZAMAN, Y. (2010): "Adoption of Tax E-Filing: a Conceptual Paper", African Journal of Business Management, vol. 4, n. 5: 599603.

BARNES, S.J.; VIDGEN, R.T. (2006): "Data Triangulation and Web Quality Metrics: A Case Study in E-Government", Information and Management, vol. 43, n. 6: 767-777. http://dx.doi.org/10.1016/j.im.2006.06.001

BERRY, L.L.; SEIDERS, K.; GREWAL, D. (2002): "Understanding Service Convenience", Journal of Marketing, vol. 66, n. 3: 1-17. http://dx.doi.org/10.1509/jmkg.66.3.1.18505

CARTER, L.; BELANGER, F. (2005): "The Utilization of E-Government Services: Citizen Trust, Innovation and Acceptance Factors", Information Systems Journal, vol. 15, n. 1: 5-25. http://dx.doi.org/10.1111/j.1365-2575.2005.00183.x

CASTANEDA, J.A.; MUNOZ-LEIVA, F.; LUQUE, T. (2007): "Web Acceptance Model (WAM): Moderating Effects of User Experience", Information and Management, vol. 44, n. 4: 384-396. http://dx.doi.org/10.1016/j.im.2007.02.003 
CHEN, S.Y.; MACREDIE, R.D. (2005): "The Assessment of Usability of Electronic Shopping: A Heuristic Evaluation", International Journal of Information Management, vol. 25, n. 6: 516-532. http://dx.doi.org/10.1016/j.ijinf omgt.2005.08.008

CHEN, J.V.; JUBILDO, R.J.; CAPISTRANO, E.P.; YEN, D.C. (2015): “Factors Affecting Online Tax: Filing - An Application of the IS Success Model and Trust Theory", Computersin Human Behavior, vol. 43: 251-262. http://dx.doi.org/10.10 16/j.chb.2014.11.017

CHO, Y.C.; SAGYNOV, E. (2015): "Exploring Factors that Affect Usefulness, Ease of Use, Trust, and Purchase Intention in the Online Environment", International Journal of Management and Information Systems, vol. 19, no. 1: 2135 .

COLWELL, S.R.; AUNG, M.; KANETKAR, V.; HOLDEN, A.L. (2008): "Toward a Measure of Service Convenience: Multiple-Item Scale Development and Empirical Test", Journal of Services Marketing, vol. 22, n. 2: 160-169. http://dx.doi.org/10.1108/08876040810862895

DAVIS, F.D. (1989): "Perceived Usefulness, Perceived Ease of Use and User Acceptance of Information Technology", MIS Quarterly, vol. 13, n. 3: 319-339. http://dx.doi.org/10.2307/249008

DELONE, W.H.; MCLEAN, E.R. (1992), 'Information Systems Success: The Quest for Dependent Variable", Information Systems Research, vol. 19, n. 3: 6095. http://dx.doi.org/10.1287/isre.3.1.60

DELONE, W.H.; MCLEAN, E.R. (2003): "The Delone and Mclean Model of Information Systems Success: a Ten-Year Update', Journal of Management Information Systems, vol. 19, no. 4: 9-30.

DIGITAL INDIA (2015), Retrieved October 10, 2015, from http://www.digitalindia.gov.in/content/introduction

FAKHOURY, R.; AUBERT, B. (2015): "Citizenship, Trust, and Behavioral Intentions to Use Public e-Services: The Case of Lebanon”, International Journal of Information Management, vol. 35, n. 3: 346-351. http://dx.doi.org/10.1016/j.i jinfomgt.2015.02.002 
FEATHERMAN, M.S.; PAVLOU, P.A. (2003): "Predicting E-Services Adoption: A Perceived Risk Facets Perspective", International Journal of Human-Computer Studies, vol. 59, n.4: 451-474. http://dx.doi.org/10.1016/S1071-5819(03)00111-3

FORD, D.P.; CONNELLY, C.E.; MEISTER, D.B. (2003): “Information Systems Research and Hofstede's Culture's Consequences: An Uneasy and Incomplete Partnership", IEEE Transactions on Engineering Management, vol. 50, n. 1: 8-25. http://dx.doi.org/10.1109/TEM.2002.808265

FORNELL, C.; LARCKER, D.F. (1981): “Evaluating Structural Equation Models with Unobservable Variables and Measurement Error", Journal of Marketing Research, vol. 18, n. 1: 39-50. http://dx.doi.org/10.2307/3151312

FU, J.R.; FARN, C.K.; CHAO, W.P. (2006): “Acceptance of Electronic Tax Filing: A Study of Taxpayer Intentions", Information and Management, vol. 43: 109-126. http://dx.doi.org/10.1016/j.im.2005.04.001

GEFEN, D.; KARAHANNA, E.; STRAUB, D.W. (2003): "Trust and TAM in Online Shopping: An Integrated Mode”, MIS Quarterly, vol. 27, n. 1: 51-90.

GUPTA, G. (2015): "Discussion of Collusive Accounting Supervision and Economic Culture”, Journal of International Accounting Research, In-Press.

HAIR, J.F.; ANDERSON, R.E.; TATHAM, R.L. (1987): Multivariate Data Analysis, New York: Macmillan.

HAIR, J.F.; BLACK, W.C.; BABIN, B.J.; ANDERSON, R.E. (2009): Multivariate Data Analysis, Upper Saddle River, NJ: Prentice Hall.

HAN, S.; BAEK, S. (2004): “Antecedents and Consequences of Service Quality in Online Banking: An Application of the SERVQUAL Instrument", Advancesin Consumer Research vol. 31, n. 2: 208-214.

HARRISON, D.A.; MYKYTYN Jr., P.P.; RIEMENSCHNEIDER, C.K. (1997): "Executive Decisions about Adoption of Information Technology in Small Business: Theory and Empirical Tests", Information Systems Research, vol. 8,n. 2: 171-195. http://dx.doi.org/10.1287/isre.8.2.171 
HOFSTEDE, G. (2001): Culture's Consequences: Comparing Values, Behaviors, Institutions, and Organizations across Nations. ( $3^{\text {rd }}$ edition). Thousand Oaks, CA: Sage Publications.

HONG, W.; THONG, J.Y.; WAI-MAN WONG, K.Y.T. (2002): "Determinants of User Acceptance of Digital Libraries: An Empirical Examination of Individual Differences and System Characteristics", Journal of Management Information Systems, vol. 18, n. 3: 97-124.

HOU, C.K. (2012): "Examining the Effect of User Satisfaction on System Usage and Individual Performance with Business Intelligence Systems: An Empirical Study of Taiwan's Electronics Industry", International Journal of Information Management, vol. 32, n. 6: 560-573. http://dx.doi.org/10.1016/j.ijinfomgt.2012. 03.001

HUANG, M.H. (2000): "Information Load: Its Relationship to Online Exploratory and Shopping Behavior", International Journal of Information Management, vol. 20, n. 5: 337-347. http://dx.doi.org/10.1016/S0268-4012(00)00027-X

HUNG, S.Y.; CHANG, C.M.; YU, T.J. (2006): "Determinants of User Acceptance of the E-Government Services: The Case of Online Tax Filing and Payment System", Government Information Quarterly, vol. 23, n. 1: 97-122. http://dx.doi.org/10.1016/j.giq.2005.11.005

KEIL, M.; BERANEK, P.M.; KONSYNSKI, B.R. (1995): "Usefulness and Ease of Use: Field Study Evidence Regarding Task Considerations", Decision Support Systems, vol. 13, n. 1: 75-91. http://dx.doi.org/10.1016/0167-9236(94)E0032-M

KIM, M.; KIM, J.; LENNON, S.J. (2006): “Online Service Attributes Available on Apparel Retail Web Sites: An E-S-QUAL Approach", Managing Service Quality, vol. 16, n. 1: 51-77. http://dx.doi.org/10.1108/09604520610639964

KIM, Y.J.; CHUN; J.U.; SONG, J. (2009): "Investigating the Role of Attitude in Technology Acceptance from an Attitude Strength Perspective", International Journal of Information Management, vol. 29, n. 1: 67-77. http://dx.doi.org/10.101 6/j.ijinfomgt.2008.01.011

KOCK, N. (2013): WarpPLS 4.0 User Manual. Retrieved May 25, 2015, from http://bit.ly/1HrxMqT 
KOCK, N.; LYNN, G.S. (2012): "Lateral Collinearity and Misleading Results in Variance-Based SEM: An Illustration and Recommendations", Journal of the Association for Information Systems, vol. 13, n. 7: 546-580.

KOERNIG, S.K. (2003): "E-Scapes: The Electronic Physical Environment and Service Tangibility', Psychology and Marketing, vol. 20, n. 2: 157-167. http://dx.doi.org/10.1002/mar.10065

KUISMA, T.; LAUKKANEN, T.; HILTUNEN, M. (2007): "Mapping the Reasons for Resistance to Internet Banking: Ameans-End Approach", International Journal of Information Management, vol. 27, n. 2: 75-85. http://dx.doi.org/10.1016/j.ijinfomgt.2006.08.006

LEE, Y.; KOZAR, K.A.; LARSEN, K.R.T (2003): “The Technology Acceptance Model: Past, Present, and Future", Communications of the Association for Information Systems, vol. 12, n. 1: 752-780.

LEE, G.; LIN, H. (2005): "Customers Perceptions of E-Service Online Shopping”, International Journal of Retail and Distribution Management, vol. 3, n. $2: 161-176$.

LEE, J.; KIM, H.J.; AHN, M.J. (2011): “The Willingness of E-Government Service Adoption by Business Users: The Role of Offline Service Quality and Trust in Technology", Government Information Quarterly, vol. 28: 222-230.

LIAO, C.; TO, P. L.; Shih, M.L. (2006): "Website Practices: a Comparison between the Top 1000 Companies in the US and Taiwan", International Journal of Information Management, vol. 26, n. 3: 196-211. http://dx.doi.org/10.1016/j.ijinfomgt.2006.02.007

LIN, F.; FOFANAH, S.S.; LIANG, D. (2011): “Assessing Citizen Adoption of EGovernment Initiatives in Gambia: a Validation of the Technology Acceptance Model in Information Systems Success", Government Information Quarterly, vol. 28, n. 2: 271-279.

LOPEZ-NICOLAS, C.; MOLINA_CASTILLO, F.J. (2008): “Customer Knowledge Management and E-Commerce: The Role of Customer Perceived Risk', International Journal of Information Management, vol. 28, 102-113. 
MORGANOSKY, M. (1986), 'Cost-Versus Convenience-Oriented Consumers: Demographic, Lifestyle, and Value Perspectives", Psychology and Marketing, vol. 3, n. 1: 35-46.

NUNNALLY, J.C, Psychometric Theory ( $1^{\text {st }}$ edition), New York: McGraw-Hill.

OJHA, A.; SAHU, G.P.; GUPTA, M.P. (2009): “Antecedents of Paperless Income Tax Filing By Young Professionals in India: An Exploratory Study", Transforming Government: People, Process and Policy, vol. 3, n. 1: 65-90.

ONG, C.S.; DAY, M.Y.; Hsu, W.L. (2009): "The Measurement of User Satisfaction with Questions Answering Systems", Information and Management, vol. 46, n. 7: 397-408. http://dx.doi.org/10.1016/j.im.2009.07.004

PARASURAMAN, A.; ZEITHAML, V.A.; MALHORTA, A. (2005): "ES-QUAL a Multiple-Item Scale for Assessing Electronic Service Quality", Journal of Service Research, vol. 7, n. 3: 213-233. http://dx.doi.org/10.1177/10946705042 71156

PAVLOU, P.; FYGENSON, M. (2006): "Understanding and Predicting Electronic Commerce Adoption: An Extension of the Theory of Planned Behavior", MIS Quarterly, vol.30, n. 1: 115-143.

PORTER, C.E.; DONTHU, N. (2006): "Using the Technology Acceptance Model to Explain How Attitudes Determine Internet Usage: The Role of Perceived Access Barriers and Demographics", Journal of Business Research, vol. 59, n. 6: 999-1007.

RAI, A.; LANG, S.S.; WELKER, R.B. (2002): “Assessing the Validity of IS Success Models: An Empirical Test and Theoretical Analysis", Information Systems Research, vol. 13, n. 1: 50-69.

RANA, N.P.; DWIVEDI, Y.K. (2015): “Citizen's Adoption of an e-Government System: Validating Extended Social Cognitive Theory", Government Information Quarterly, vol. 32, n. 2: 172-181. http://dx.doi.org/10.1016/j.giq.2015.02.002

ROWLEY, J. (2006): “An Analysis of the E-Service Literature: Towards a Research Agenda", Internet Research, vol. 16, n. 3: 339-359. 
SCHWARTZ, S.H. (1994): “Are There Universal Aspects in the Structure and Contents of Human Values?”, Journal of Social Issues, vol. 50, n. 4: 19-45.

SCHWARTZ, S.H.; CIECIUCH, J.; VECCHIONE, M.; DAVIDOV, E.; FISCHER, R.; BEIRLEIN, C.; RAMOS, A.; VERKASALO, M.; LONNQVIST J.; DEMIRUTKU, K.; OZLEM, D.; KONTY, M. (2012): "Refining the Theory of Basic Individual Values”, Journal of Personality and Social Psychology, vol. 103, n. 4: 663-688. http://dx.doi.org/10.1037/a0029393

SHIH, H.P. (2004): “An Empirical Study on Predicting User Acceptance of EShopping on the Web", Information and Management, vol. 41, n. 3: 351-368.

SRINIVASAN, S.S.; ANDERSON, R.; PONNAVOLU, K. (2002): “Costumer Loyalty in Ecommerce: An Exploration of its Antecedents and Consequences", Journal of Retailing, vol. 78, n. 1: 41-50.

SRITE, M.; KARAHANNA, E. (2006): "The Influence of National Culture on the Acceptance of Information Technologies: An Empirical Study”, MIS Quarterly, vol. 30, n. 3: 679-704.

THE ECONOMIST (2015): A Chance to Fly. Retrieved October 10, 2015, from http://econ.st/1Pyj1DJ

TORKZADEH, C.; DHILLON, G. (2002): "Measuring Factors that Influence the Success of Internet Commerce", Information Systems Research, vol. 13, n. 2: 187204. http://dx.doi.org/10.1287/isre.13.2.187.87

UDO, G.J.; BAGCHI, K.K. (2011): "Understanding the Influence of Espoused Culture on Acceptance of Online Services in a Developing Country", Journal of Information Technology Theory and Application, vol. 12, n. 2: 25-46.

UDO, G.J.; BAGCHI, K.K.; KIRS, P.J. (2008): “Assessing Web Service Quality Dimensions: The E-SERVPERF Approach", Issues in Information Systems, vol. 9, n. 2: 313-322.

UDO, G.J.; BAGCHI, K.K.; KIRS, P.J. (2010): “An Assessment of Customers’ EService Quality Perception, Satisfaction and Intention”, International Journal of Information Management, vol. 30: 481-492. http://dx.doi.org/10.1016/j.ijinfomgt. 2010.03.005 
UNITED NATIONS E-GOVERNMENT SURVEY (2014), Retrieved May 18, 2015, from http://bit.ly/1o3xTf8

VENKATESH, V.; MORRIS, M.G.; DAVIS, G.B.; DAVIS, F.D. (2003): “User Acceptance of Information Technology: Toward a Unified View”, MIS Quarterly, vol. 27, n. 3: 425-478.

WALLACE, L.G.; SHEETZ, S.D. (2014): "The Adoption of Software Measures: A Technology Acceptance Model (TAM) Perspective", Information and Management, vol. 51, n. 2: 249-259

YOON, C. (2009): "The Effects of National Culture Values on Consumer Acceptance of E-Commerce: Online Shoppers in China", Information and Management, vol. 46, n. 5: 294-301.

ZEITHAML, V.A.; BERRY, L.L.; PARASURAMAN, A. (1996): "The Behavioral Consequences of Service Quality", Journal of Marketing, vol. 60, n. 2: 31-46. http://dx.doi.org/10.2307/1251929

ZHANG, X.; PRYBUTOK, V.R. (2005): "A Consumer Perspective of E-Service Quality”, IEEE Transactions on Engineering Management, vol. 52, n. 4: 461-477. http://dx.doi.org/10.1109/TEM.2005.856568 